\title{
6
}

\section{RESPONSES TO TORONTO'S AFFORDABLE HOUSING CHALLENGE}

\author{
Mobilizing for Action
}

\author{
Sean Gadon
}

\section{Introduction}

Toronto is Canada's largest city, the fourth largest city in North America, and home to a diverse population of about 2.9 million people. Over the past decade, Toronto has witnessed an unprecedented residential building boom and a hot housing market for consumers. Toronto leads North American cities in residential construction projects, building on average some 16,000 new residential units annually. Meanwhile, social housing waiting list has grown, with some 100,000 households waiting to access 94,000 social housing homes (Kneebone and Jadidzadeh, 2017). Vacancy rates in market rental housing have declined to $0.7 \%$ - the lowest rate in 16 years. Close to half of renters (47\%) spend more than $30 \%$ of their income on housing - this trend is expected to worsen, with the number of households in core housing need growing by 44,000 by 2030 , equivalent to twice the rate over past 12 years. Average home prices have skyrocketed, leaving tenants locked into rental housing and reducing mobility from rental housing. From 2006 to 2018, median household income grew only 30\%, while average homeownership costs grew 131\% (Canadian Centre for Economic Analysis and Canadian Urban Institute, 2019).

\section{Toronto's Open Door Affordable Housing Program}

In 2009, Toronto City Council adopted a ten-year Housing Opportunities Toronto Action Plan (HOT) 2010-2020. This plan set out the goal of achieving on average 1,000 new rental units annually, or 10,000 over the ten-year period. By the end of 2015, the number of new affordable rental approvals reached 1,154, and it was clear that the City was falling short of achieving its affordable housing targets (Figure 6.1).

With the support of the new Mayor of Toronto and the City's Housing Advocate, officials were tasked with revamping the City's approach in an effort to meet the annual target of 1,000 units for the period 2016-2020. In 2016, City Council approved a new initiative called the Open Door Program. This unilateral City programme set out a consistent approach to the approval of new affordable rental housing through a partnership with non-profit and private sector organizations (City Planning Division, 2018).

The essential elements of the Program provide for a suite of financial incentives, including the waiver of development charges, planning application fees and building permit fees, and the 


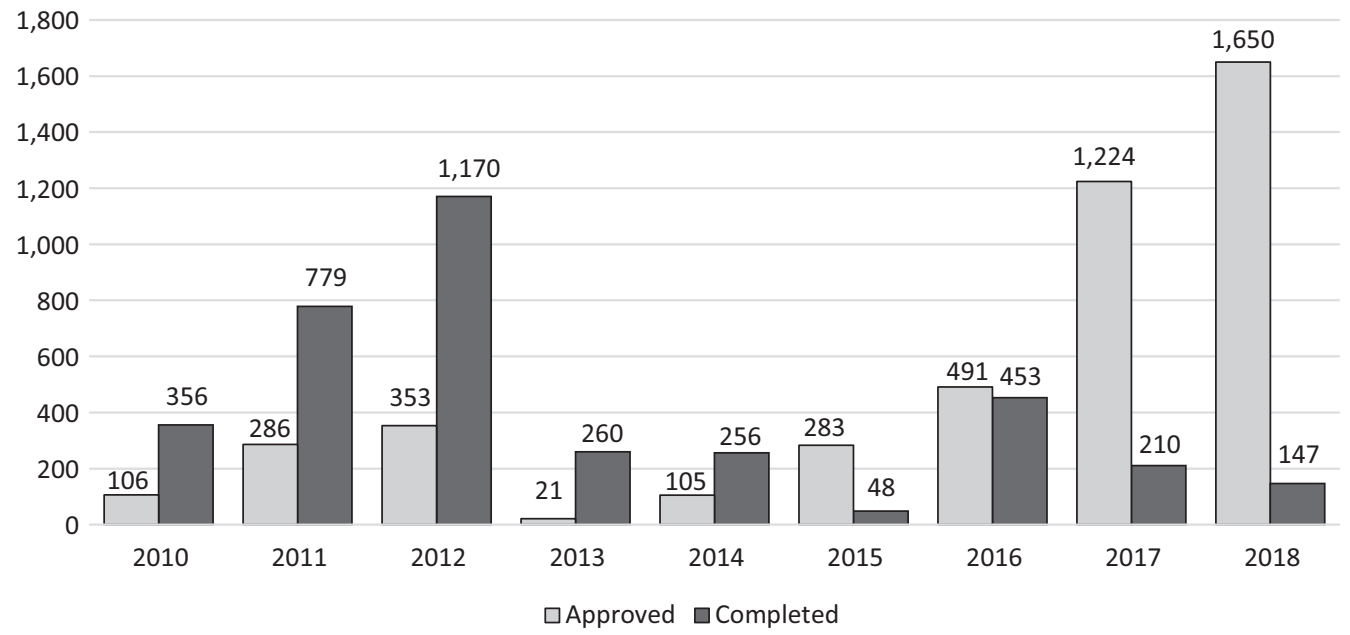

FIGURE 6.1 New Affordable Rental Homes Approved and Completed in Toronto, 2010-2018. Source: City of Toronto's Affordable Housing Office, August 2018.

waiver of property taxes over the period of operating the affordable housing units. Capital funding has also been added to the Program to ensure project viability. In total, the value of these investments over a five-year period is $\$ 222$ million. Approved Open Door developments were also ensured they get an expedited planning approval process. Further, the Program committed the City to providing select surplus land sites for both affordable rental and ownership housing.

Overall reception to the Program has been positive. Program applications have been robust, and for the years 2017 and 2018, approved projects have exceeded the annual target of 1,000 units. The reasons often cited for the success of the Program include its flexible nature as it provides early certainty to non-profit and private sector organizations on the City's commitments to affordable housing and to their specific project. The approval of projects in the early stages creates a pipeline of developments and eliminates the challenging feature of other affordable housing programmes for developments to be shovel-ready. The Program also provides opportunities throughout the development process to stack other funding to support the construction of the project and/or during the operating phase (CBRE Limited, 2017). Additionally, the Program provides the flexibility to proposed mixed-market and affordable developments, with a requirement that a minimum of $20 \%$ of the gross floor area be developed as affordable rental. The Program also has three "portals" through which affordable rental housing development partnerships can be approved. This includes approvals through annual proposal calls, through the final planning application approval process, and through special initiatives such as the Ontario Affordable Housing Provincial Lands Program.

At the same time, the Open Door Program has also attracted a range of criticisms. Most recently, housing advocates have called for the Program to provide rents on a rent-geared-toincome basis at no more than $30 \%$ of a household income. Currently, the Program sets rents at the City's Official Plan definition of no more than the average market rent for Toronto as published annually by Canada Mortgage and Housing Corporation (Figure 6.2).

Non-profit groups have also been critical of the fact that the Program does not guarantee affordability in perpetuity. The minimum affordability period for the Program is 25 years. The "pipeline" approach of providing early project approvals rather than shovel-ready projects has increased the risk of some projects not proceeding. The longer development and completion schedules have also resulted in some level of frustration being expressed by local politicians and the public who are looking for immediate results and quick fixes. 


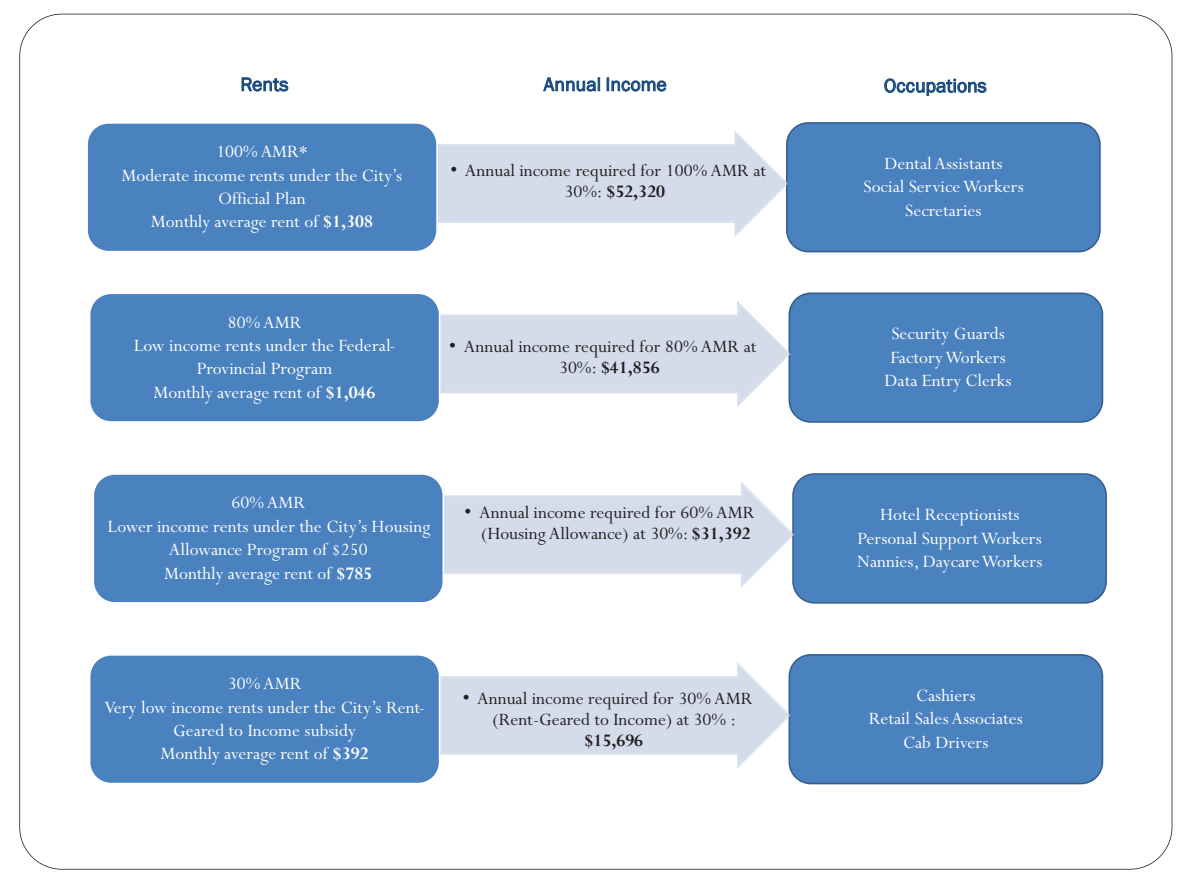

FIGURE 6.2 Toronto Housing Rents and Affordability by Income Band. Source: City of Toronto's Affordable Housing Office, August 2018.

\section{Leveraging Public Land to Deliver Affordable Housing}

It is now some 21 years ago that the new City of Toronto was created through the amalgamation of five local governments and the metropolitan regional government. Over this period of time, a series of public land initiatives impacting the development of affordable housing has emerged.

\section{Leveraging Public Housing Land}

Following the municipal amalgamation in Toronto and the provincial transfer (downloading) of housing to Ontario municipalities, the new City was faced with a decision on how to administer the various public housing agencies - specifically the Metro Toronto Housing Company, CityHome, and the Metropolitan Toronto Housing Authority (Golden, 1999). In 2000, City Council amalgamated the three public housing agencies into a new arms-length corporation named Toronto Community Housing Corporation (TCHC). Almost 60,000 residential units were transferred to TCHC, and the new corporation was given broad independent powers to operate.

Immediately following the creation of TCHC, the new leadership developed a public/private sector model of public housing revitalization. This model provided for the replacement of large public housing communities with new mixed-income communities by leveraging profits from the sale of public land to provide for the full replacement of social housing. Most importantly, the revitalization guaranteed the right of return to every social housing resident. The public housing revitalization projects approved by TCHC and City Council were bold, long-term, and unprecedented billion-dollar social and economic investments undertaken in partnership with the private development community and impacted residents.

Today, there are six major revitalization initiatives underway representing the replacement of some 4,805 rent-geared-to-income social housing homes and the addition of 13,500 new market ownership homes. The revitalization sites include Regent Park, Alexandra Park, Lawrence 
Heights, Allenbury Gardens, Leslie Nymark, and 250 Davenport Road. In Regent Park, so far some 1,002 new affordable rental homes have been built through leveraging $\$ 70$ million of federal/provincial affordable housing funding and $\$ 37.5$ million in City financial incentives. The revitalization of these communities has been achieved through the application of planning and social development principles supporting strong "complete communities". As a result, in addition to the creation of replacement and new housing units, the formerly isolated public housing projects are re-integrated into the adjacent community through reconnecting the street grid, the inclusion of new community facilities, the fostering of new commercial uses, and the employment of public housing residents throughout the process (City Planning Division, 2018).

\section{The West Don Lands Public Lands Affordable Housing Legacy}

The West Don Lands are located in downtown Toronto near the west side of the mouth of the Don River (Figure 6.3). The area consists of 80 acres of land and historically supported land uses of heavy industry, stockyards, scrapyards, rail uses, and a distillery. In 1987, in response to the need for new affordable housing, the Province of Ontario and the City of Toronto announced the multimillion-dollar expropriation of all of the businesses within the West Don Lands. The catalyst for change came in 1999 with a federal, provincial, and City tri-government agreement to support Toronto's bid for the 2008 Olympic Games. This effort led to an agreement to establish a new trigovernment agency Waterfront Toronto. The new agency was given funding and responsibility to lead the development of 2,000 acres of brownfield lands on Toronto's waterfront into beautiful, accessible, sustainable mixed-use communities and dynamic public spaces. This included the full build out of 40,000 new homes (Marr, 2015). Working with local residents groups and Waterfront Toronto, the City designated the area as Regeneration Area and Parks and Open Space Areas. This plan placed a requirement that $20 \%$ of all new residential housing be required to be developed as affordable rental housing, thus guaranteeing a mix of incomes in the community.

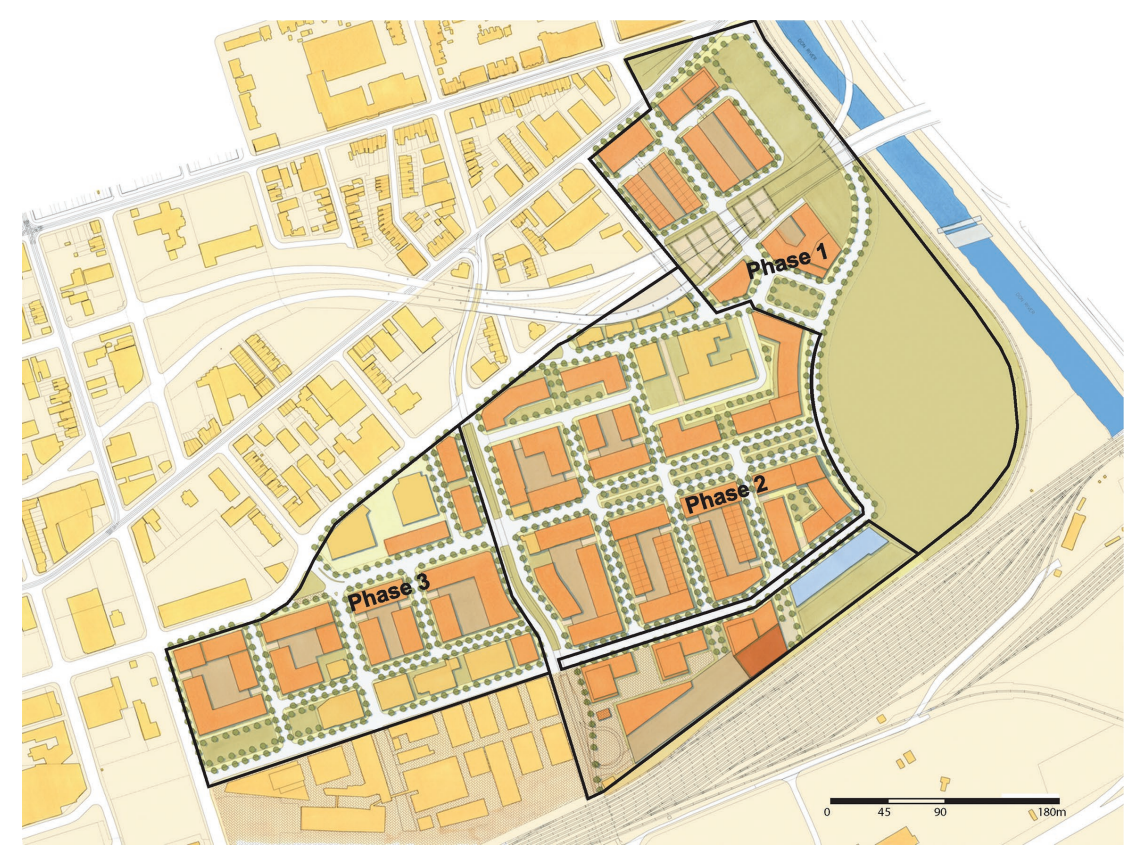

FIGURE 6.3 West Don Lands Phasing Plan.

Source: City of Toronto. 


\section{Phase One - New TCHC Homes}

While the 2008 Olympic Games were ultimately awarded to Beijing, the City's Olympic bid had created the momentum needed to kick-start the first phase of the West Don Lands redevelopment process. After many years of planning and false starts, by 2014, the first phase of the community was beginning to take shape. Key infrastructure requirements were in place, including the construction of a flood protection berm, the design and build out of the 18 acre Corktown Common Park, and the completion of new residential housing.

Critical to the successful implementation of the first phase of development was the reaching of an agreement in 2009 among Waterfront Toronto, the Ontario government, and the City of Toronto that they would provide serviced and clean land available at no cost to support the development of the affordable rental housing. The West Don Lands Affordable Housing Agreement provided the foundation for a partnership among the parties to support TCHC in the construction of 243 new affordable seniors and family TCHC rental homes at River Street and King Street West. Investments from the federal/provincial Affordable Housing Program, the City of Toronto, and TCHC provided the capital to construct the homes. The first phase development of West Don Lands was underway, but what about phases two and three where the majority of the land still remained vacant? A further catalyst was soon on the horizon. That catalyst came in the form of the provincially backed City bid to host the Pan American Games in 2016.

\section{Phase Two - New Non-Profit Homes}

Through strong leadership from the Ontario government and the former Premier David Peterson, the City won the bid to host the Pan American Games in 2015. The bid plan called for the creation of a village in the West Don Lands to house the expected 10,000 athletes. As the owners of the West Don Lands, the provincial agency Infrastructure Ontario (IO) assumed the lead in securing a private development partner and ensuring the buildout of the next phase on time and on budget. Through a special Pan Am Office, the City coordinated the involvement of various City divisions throughout and during the Games. Most importantly, IO and the Ontario Ministry of Housing engaged the City's Affordable Housing Office in the detailed planning, approving the specifications and selection of two non-profit organizations who would own and operate 253 units of affordable housing in two rental buildings (City Planning Division, 2018).

This unique arrangement where the master developer of the Pan Am Village and the Province of Ontario would build and turn over the ownership of the buildings to the new owners and operators was the first of its kind in Toronto. This unique partnership resulted in new affordable non-profit housing for Fred Victor Homes to provide housing for low-income and vulnerable residents and Wigwamen to provide housing focused on the needs of indigenous residents.

\section{Phase Three - The Public/Private Partnership}

With the Pan Am Games successfully completed, attention turned to how to maintain the momentum in building out the new community. The key issue was how to fund the build out of the affordable rental housing. This time the catalyst came not from a sporting event, but directly from Toronto's overheated housing market. With rapidly rising house prices in the Greater Toronto Area, a shortage of affordable rental accommodation, and cases of evictions from rent increases, the federal, provincial, and City governments all introduced measures to "cool" the housing market and provide new supply (Marr, 2015). In particular, the province introduced the Ontario Fair Housing Plan and the Ontario Affordable Housing Lands Program. 
The first phase of the Ontario Affordable Housing Lands Program identified Blocks 3W, 4W, 7W, 8 , and 20 in the West Don Lands for new residential development. In working with the City of Toronto, the Province created a new public/private sector development model where

the primary objective through this premier urban land site offer is to leverage the prized land value of Sites in exchange for a conscientiously designed mixed market and affordable rental housing development. To this effect, the collective vision for the Properties is that they are specifically developed in a manner that effectively marries a broad range of residential unit layouts and accommodates a wide diversity of low to high income residents.

The West Don Lands offering provided a total of 550,000 sq. ft. of residential and mixed-use density where the builder/operator would be required to provide $30 \%$ of the residential units (390) at affordable rent levels, $10 \%$ at $40 \%$ of average market rent, and $40 \%$ at $80 \%$ of average market rents for a lease term of 99 years. In return for providing the affordable housing, the developer obtained a 99-year discounted leased to reduce upfront land costs. As part of the package, the City pre-approved Open Door Program municipal financial incentives for the affordable housing units. The incentives included waiver of planning, building and development charge fees, and property taxes for the duration of the lease. The planning approvals are also being fasttracked. It has taken some 30 years, but the Toronto-Ontario vision of a new mixed-income community in the West Don Lands is finally being realized. At present, 886 affordable rental homes are being developed due to strong public/private partnerships leveraging the essential value of public lands in delivering affordability.

Municipal governments, compared to other orders of government, do not have the same means to fund housing initiatives. Despite this, cities have been and continue to be leaders in innovation, by using their resources to create the right conditions for other governments to invest (Woetzel et al., 2014). This local leadership is often the catalyst for other governments to act (Hern, 2010). The Housing Now Initiative is no different. To meet the public expectations on housing, the City created a programme that takes the first step, the initial leadership, to create new affordable housing in Toronto. The City is using the tools at its disposal, specifically leveraging municipal surplus land at higher-order transit locations to create housing opportunities. This is the genesis behind Toronto's Housing Now Initiative, and ultimate success will require investments from all governments.

\section{Housing Now Initiative}

Launched by Mayor Tory in October 2018, the initiative focuses on activation of public land for new affordable housing for immediate development. This created a great opportunity for City staff to develop a programme to address affordable housing but also develop mix-income transitoriented communities. The approach was a distinct break from past business practices where the City's disposition of surplus municipal land sought to achieve the highest financial return.

\section{Housing Now Delivering Affordable Rental Homes}

Through the Housing Now Initiative, the City is leveraging the value of surplus municipal land, providing municipal financial incentives, and is providing a high level of certainty for the development community by pre-zoning sites. These are real and tangible benefits that help support the business case for the overall development, including the new long-term affordable rental housing. The affordable rental homes are targeted to serve households earning between $\$ 21,000$ 
TABLE 6.1 Housing Now, Affordable to Whom?

\begin{tabular}{|c|c|c|c|}
\hline Market Asking Rent & Annual Income & Annual Income & $\begin{array}{l}\text { Housing Now Target } \\
(80 \% A M R)^{\mathrm{a}}\end{array}$ \\
\hline & $\$ 20,000$ & $\$ 20,000$ & \\
\hline & $\$ 30,000$ & $\$ 30,000$ & Bachelor $\$ 871$ \\
\hline & $\$ 40,000$ & $\$ 40,000$ & 1-Bedroom $\$ 1,106$ \\
\hline & $\$ 50,000$ & $\$ 50,000$ & 2-Bedroom $\$ 1,193$ \\
\hline Bachelor $\$ 1,399$ & $\$ 60,000$ & $\$ 60,000$ & 3-Bedroom $\$ 1,325$ \\
\hline 1-Bedroom $\$ 1,738$ & $\$ 70,000$ & $\$ 70,000$ & \\
\hline 2-Bedroom $\$ 2,026$ & $\$ 80,000$ & $\$ 80,000$ & \\
\hline 3-Bedroom $\$ 2,298$ & $\$ 90,000$ & $\$ 90,000$ & \\
\hline Early childhood educator & Retired/pensioner & Welder & Employment counsellor \\
\hline Annual income $\$ 33,150$ & Annual income $\$ 38,400$ & Annual income $\$ 44,850$ & Annual income $\$ 52,000$ \\
\hline
\end{tabular}

Source: Based on data by CreateTO, September 2019.

a Average market rent (AMR) figures are used to set affordable housing monthly occupancy costs, with different affordable housing programmes charging $100 \%$ or $80 \%$ of AMR, depending on their agreement.

and $\$ 52,000$ per year who would pay no more than $30 \%$ of their gross income in housing costs (see Table 6.1). These households represent residents who are key workers within the Toronto economy but are unable to find and keep affordable housing in the private rental market where rents for comparable units are $\$ 600-\$ 1,000$ higher. In addition, some rental homes may be more deeply affordable through working with non-profit organizations who have access to rent-geared-to-income funding programmes and/or though housing allowance programmes (City Manager's Office, 2019).

\section{Building Non-Profit Housing Capacity and Non-Profit Engagement}

In approving the Housing Now Initiative, the City established a $\$ 1$ million non-profit capacity building fund. The fund is designed to support non-profit organizations who are bidding themselves, as part of a non-profit consortium or in partnership with a private sector developer. Non-profits have the experience in knowing what works in terms of physical design and building specifications. Non-profit organizations also have a wealth of expertise in the management and operation of housing, including with tenant groups with low-incomes, special needs, and requiring support services. Non-profit housing organizations can also provide a "tenants first" perspective focusing on resident selection, maintaining a residents housing stability, and improving the quality of life of residents (CreateTO, 2019).

Phase One identifies 11 surplus City properties located at higher-order public transit corridors. The City prioritized four sites to be expedited through the planning approval and market offering process in 2019 with construction to start in 2020/2021. The additional seven sites are planned to come forward in 2020 (Richardson, 2019). Extensive public engagement also occurred.

\section{Challenges and Opportunities}

The Housing Now Initiative represents a new approach to City building and leveraging the value of surplus City properties. The activation of 11 sites is the first phase of a programme intended to support the City's target of providing 40,000 new affordable rental homes between 2018 and 2030. The challenges include: 
- Managing public expectations on the speed and delivery of the Housing Now sites given that the development and completion of the new affordable housing is a multi-year process - yet the need for affordable housing is immediate.

- Recognizing the limitations of delivering long-term affordable housing rental and mixedincome communities without upfront federal/provincial capital and operating funding - in essence, there is a limit on how much affordable housing can be secured when leveraging the value of surplus municipal land and municipal financial incentives.

- Scaling-up of the Housing Now Initiative beyond City sites to achieve a 40,000 affordable rental housing target within 12 years.

- Shifting the focus of the building industry away from a condominium development business model to new mixed-income model that addresses the need for purpose-built rental affordable and market housing.

The opportunities include:

- Restoring public confidence in the role and power of government to use land-use planning and public programmes to deliver urgent public benefits.

- Contributing to providing a range of City-building goals such as creating new mixedincome communities and providing new neighbourhood amenities such as childcare and community hubs.

- Supporting the City's purpose-built private rental housing industry and non-profit housing sectors.

- Kick-starting new affordable and mixed-income housing development with the expectations that the federal and provincial governments will participate through their respective programmes.

- Providing long-term secure and affordable rental homes for low- and moderate-income households who are at the forefront of Toronto's housing crisis.

\section{Conclusion: Developing and Implementing a New Approach}

Addressing the affordable housing crisis through strategies to increase the supply of affordable rental housing has emerged as a top priority in Toronto. The City has developed a range of programme and policy tools to stimulate new supply (National Housing and Homelessness Network, 2004). In particular, Toronto's Open Door Program provides a range of incentives to eligible non-profit and private builders. In efforts to scale-up new affordable rental housing, governments must look carefully at the importance of public land to leverage affordable rental housing in new developments. This applies to existing land assets and the potential to secure strategic land sites for affordable housing such as through purchase, expropriation, and inclusionary zoning practices (Hulchanski, 2010).

The City of Toronto's experience and track record demonstrate that it is possible to successfully develop new mixed-income communities and new affordable housing on existing and surplus municipal lands. The example of success of leveraging partnerships for affordable rental housing is the 30-year partnership between the Ontario government and the City of Toronto. While not the silver bullet solution to the urban affordable housing crisis, the strategic use of public land has an important role in contributing to solutions today and for generations to come.

Municipal governments play different roles with respect to housing. Traditionally, planning departments direct where housing should be located through Official Plans and issue planning approvals; the building department issues permits and inspects construction; the City administers 
federal and provincial housing infrastructure funds and programmes (Hellyer, 1969). Working in different City divisions, it is often easy to function in silos and continue operating under the status quo. This need not be the case; while municipal resources are scarce, there are ways to break down silos and drive a housing agenda from inside municipal government.

Housing Now was introduced in 2018, but its components are not new - the City has always disposed of land, and planning approvals could be streamlined and fees waived (City Manager's Office, 2019). The opportunity presented itself to align these functions to address a housing crisis in the City while leveraging federal support (Government of Canada, 2017). The mayor and City Council shifted the priority from selling off City land for revenue to using it to build housing. It called for coordination and accountability to get results; thus, a new Housing Secretariat was created to ensure that the work was coordinated and on track. While there have been some challenges along the way, this new coordinated approach that responds to the issues raised by developers and non-profit sector to expedite approvals and provide low-cost land will address housing affordability challenges in Toronto. As Toronto proceeds with the Housing Now Initiative and other measures to scale-up towards a achieving a goal of 40,000 affordable rental homes, the real measure of success will be in getting shovels in the ground, having new residents move in, and ultimately producing thriving new healthy mixed-income communities.

\section{Acknowledgements}

This chapter has been prepared with input and assistance of Mercedeh Madani and Minha Hassim, Policy Development Officers, Housing Secretariat. Views expressed in this chapter are those of the author.

\section{References}

Canadian Centre for Economic Analysis and Canadian Urban Institute (2019). Toronto Housing Market Analysis. City of Toronto. Retrieved October 1, 2019 from www.toronto.ca/legdocs/mmis/2019/ph/ bgrd/backgroundfile-124480.pdf.

CBRE Limited (2017). Land Portfolio Offering for the Provincial Affordable Land Program. Toronto: CBRE.

City Manager's Office (2019). Implementing the Housing Now Initiative, City of Toronto. Retrieved October 1, 2019 from www.toronto.ca/legdocs/mmis/2019/ex/bgrd/backgroundfile-123663.pdf.

City Planning Division (2018). Rental Housing Market Conditions in Toronto, City of Toronto. Retrieved September 13, 2018 from www.toronto.ca/legdocs/mmis/2018/td/bgrd/backgroundfile112710.pdf.

CreateTO (2019). Housing Now Initiative. Retrieved October 1, 2019 from https://createto.ca/housingnow/ Golden, A. (1999). Taking Responsibility for Homelessness: An Action Plan for Toronto: Report of the Mayor's Homelessness Action Task Force. Toronto: City of Toronto.

Government of Canada (2017). Canada’s National Housing Strategy. Retrieved September 13, 2018 from www.placetocallhome.ca/pdfs/Canada-National-Housing-Strategy.pdf.

Hellyer, P. (1969). Report of the Task Force on Housing and Urban Development. Ottawa: Government of Canada: 41-43.

Hern, M. (2010). Common Ground in a Liquid City: Essays in Defence of an Urban Future. Toronto: AK Press, Government of Canada.

Hulchanski, D. (2010). The Three Cities within Toronto Income Polarization among Toronto's Neighbourhoods, 1970-2005, Cities Center, University of Toronto. Retrieved September 13, 2018 from www.urbancentre.utoronto.ca/pdfs/curp/tnrn/Three-Cities-Within-Toronto-2010-Final.pdf.

Kneebone, R., and Jadidzadeh, A. (2017). An Analysis of Homeless Shelter Use in Toronto, 2011-2016. Toronto: City of Toronto Shelter, Support and Housing Administration. Retrieved September 13, 2018 from www.toronto.ca/wp-content/uploads/2017/10/97c8-SSHA-Analysis-of-shelter-use20112016.pdf. 


\section{Sean Gadon}

Marr, G. (2015). Toronto's Residential Land Prices Reach New Highs: "More Condominiums Coming”. Financial Post. Retrieved September 12, 2018 from https://business.financialpost.com/personalfinance/mortgages-realestate/torontos-residential-land-prices-reach-new-highs-more-condominiums-coming.

National Housing and Homelessness Network (2004). "Ending Homelessness: The One Percent Solution", in Hulchanski, D., and Shapcott, M. (eds). Finding Room: Policy Options for a Canadian Rental Housing Strategy. Toronto: Centre for Urban and Community Studies, University of Toronto: 381-387.

Richardson, M. (2019). "Is John Tory’s Housing Now Plan Crumbling?” Spacing. Retrieved October 5, 2019 from http://spacing.ca/toronto/2019/10/02/is-john-torys-housing-now-plan-crumbling/.

Woetzel, J., Ram, S., Mischke, J., Garemo, N., \& Sankhe, Sh. (2014). A Blueprint for Addressing the Global Affordable Housing Challenge. Zurich: McKinsey Global Institute (MGI) Report. 